\title{
Corporate Social Responsibility reporting of banks operating in Ghana
}

\section{Authors: \\ Mr Kwamena Minta Nyarku' \\ Prof Robert Ebo Hinson ${ }^{1,2}$ \\ Affiliation: \\ ${ }^{1}$ University of Ghana \\ ${ }^{2}$ University of the Free \\ State, South Africa}

\section{Correspondence to:}

Mr Kwamena Minta

Nyarku,

Department of Marketing and Entrepreneurship,

University of Ghana

Business School,

Legon, Accra

Ghana

Tel:

+233541750910

\section{E-mail:}

knyarku@ucc.edu.gh kmnyarku001@st.ug.edu rhinson@ug.edu.gh hinsonrobert@gmail.com

\section{DOI:}

10.15249/11-2-146

\section{Keywords:}

corporate social responsibility (CSR); disclosures; reporting banking industry; Ghana; annual reports

\section{Abstract}

This study sought to track corporate social responsibility (CSR) reporting of local and foreign banks in Ghana from 2010-2014 financial year ends. Employing a qualitative approach, the study examined 50 annual reports sourced from the selected banks' websites. The findings recorded more external than internal CSR disclosures. Concerning internal disclosures, only one foreign bank reported product and customer initiatives whilst one local and four foreign banks reported human resource initiatives. External disclosures reported uneven community involvement and environmental focus among the selected banks. Predominantly, the issues on health, education and sports development dominate Ghana's banking industry CSR initiatives and disclosure.

\section{Introduction and background to the study}

Over the last 63 years, corporate social responsibility (CSR) has been recognised as a significant conception that is prioritised in both professional and academic practices, and has aided organisations to achieve sustainable competitive advantages. Stakeholders judge companies' efforts based on available information, especially with the growing concern about ethical and social issues. Communication plays a critical role in the CSR agenda but lacks the necessary attention (Ihlen, Barlett \& May, 2014), and appears to be silent on CSR practices and studies (Schmeltz, 2012). As a result, some authors (Morsing \& Shultz, 2006), have called for a more advanced communication approach, including stakeholder awareness of firms' CSR activities and performance (Sloan, 2009:34). 
Despite the growing skepticism that some companies overemphasise their social behaviour (Holme \& Watts, 2000), there is deficiency in significance and reliability of such behaviour (Husillos, Larrinaga \& Alvarez, 2011), and failure impact sustainable growth (Gray, 2010). Isenmann (2006) hinted that companies must use various media to communicate with their stakeholders about the changing business practices concerning local, national and global societal expectations. According to Nielsen and Thomsen (2012), CSR disclosure appears not to have a considerable impact on conventional CSR literature.

Stakeholder benefits and CSR motives are often communicated (Du, Bhattacharya \& Sen, 2010), and Gray, Kouhy and Lavers (1995) shared the view that special publications, socially oriented advertising and proposed information in the annual report are appropriate for communication. Maignan and Ferrell (2004) also contended that how CSR is communicated is still under study, and "for most companies, the question is not whether to communicate but rather what to say, to whom, and how often" (Kotler, 2003:563).

According to Branco and Rodrigues (2006), CSR reporting is the expose of information concerning companies' exchanges with the society within which they operate. Guthrie, Cuganesan and Ward (2008) and Visser (2008) have emphasised the urgent need for scholars to examine CSR reporting in different industries. Although Poolthong and Mandhachitara (2009) have hinted that socially responsible programs are employed by financial institutions to enhance their reputation, the CSR initiatives required to put together encouraging stakeholder responses (Chomvilailuk \& Butcher, 2013), are still unclear. Meanwhile, scholars have also argued that firms with a strong orientation toward disclosure of social responsibility actions and initiatives are well capable of developing and maintaining a good and long-term relationship with key stakeholders (Kitora \& Okuda, 2017).

Although online CSR reporting has been investigated in a number of sectors such as in the insurance sector (Hinson, Zyl \& Agbleze, 2014); firm's starting point and industry area (Wanderley, Lucian, Farache \& De Sousa Filho, 2008); and banks (Hinson, Boateng \& Madichie, 2010; Hinson, 2011), studies by financial institutions on CSR disclosures (Hamid, 2004) remain very scanty. It is in line with the paucity of studies in this area that Ullmann (1985) has appealed for more longitudinal studies to be conducted on CSR engagements.

Studies on banks' CSR reporting which used longitudinal approaches are rare in Ghana and since banks play a "catalytic role" towards sustainable management and disclosure towards fulfilling stakeholder interests (Islam, 2013), it is the researchers' view that this study will craft an imperative input to existing CSR and CSR reporting literature. Reflecting on the aforementioned gaps which include limited CSR reporting studies and the dearth of CSR longitudinal studies in Ghana's banking sector, this current study sought to track the CSR disclosures of local and foreign-owned banks (which are privately owned) operating in Ghana from 2010-2014 financial year ends by way of annual reports posted on their respective corporate websites. What CSR disclosures are recorded by 
local and foreign banks in Ghana as posted in their annual reports sourced from their respective bank websites? Drawing on Branco and Rodrigues' (2006) CSR reporting online framework, this article is also grounded in legitimacy and stakeholder theoretical perspectives.

According to Narteh (2013), the Bank of Ghana (BoG) is mandated to ensure sustainable development in productivity and employment by providing the right environment for the economy of Ghana, and predominantly the banking sector. This is because, according to Bawumia, Owusu-Danso and Mclntyre (2008), the banking sector accounted for about $70 \%$ of the financial sector, and its role in capital concentration and distribution has been phenomenal. Again, the sector controls price immovability, lowers price increases and supports government's efforts to ensure sound macroeconomic stability.

The Ghana Banking Survey (2014) reported a slowdown in deposit mobilisation, despite the consequences of the $33 \%$ growth in total assets in 2013 compared to an average growth rate of only $26 \%$ recorded between 2008 and 2012. There are 27 universal banks in Ghana, and as at 2012 statistics show, 10 of these banks are locally owned whilst the remainder are co-owned by a blend of African banking groups, Americans and Europeans. The banking sector is also made up of 137 rural banks and 58 non-bank financial institutions respectively, which covers finance houses, leasing and mortgage, and savings and loans firms. Currently, there are 12 locally owned banks in Ghana.

This study is a recent investigation into banks' CSR reporting in Ghana over a five-year period and has contributed to the progress and significance of CSR reporting towards enhancing banks' CSR practices. It has also exposed the position of CSR reporting in the banking industry, as well as the areas of CSR engagements, by revealing the actual differences of CSR disclosures between local and foreign banks. Again, the CSR disclosure position has exposed the need for Ghana's government to establish CSR regulation to enhance the contributions of banks' CSR engagements towards the national development agenda. Again, this article, which appears to be the first of its kind in Ghana, has confirmed that CSR reporting that requires longitudinal studies is indispensable and merits further consideration, more than ever, in developing countries. The study has also contributed to the knowledge gap in the CSR reporting literature and has contributed and responded to Ullmann's (1985) appeal for more CSR longitudinal studies.

\section{Literature review}

\subsection{Theoretical perspectives}

Some researchers (Arvidsson, 2010; Branco \& Rodrigues, 2006) have relied on legitimacy and stakeholder theories in discussing CSR in CSR communication. Some scholars (Tuokuu \& Amponsah-Tawiah, 2016) have contended that "CSR takes its roots from the stakeholder theory", and if organisations fail to receive stakeholders' cooperation, "CSR programmes cannot be executed" (Huang \& Zhao, 2016). The stakeholder theory, according to Maignan and Farrell (2004), seeks to advocate that firms consider other 
goals in addition to profit maximisation and irrespective of the nature, size and type of business; companies that invest in CSR will achieve positive benefits. Predominantly, the stakeholder approach to CSR studies has focused on financial institutions' social responsibility disclosures (Ofori \& Hinson, 2007) and social responsibility communication (Porter \& Kramer, 2006).

The prevailing interpretative lens in sustainability reporting literature is the legitimacy theory, a view shared by Owen (2008). The theory tends to emphasise organisations' dependence on the environment, society's changing expectations and legitimising their organisations' actions (Newson \& Deegan, 2002). To gain community approval, particular information to convince all stakeholders that companies' engagements are supportive and legitimate, must be voluntarily disclosed (Alawi \& Rahman, 2011). This process can be achieved through communication (Ihlen, May \& Barlett, 2014). Again, as hinted by Glennie and Lodhia (2013), countries and industries with stronger environmental agendas often employ the legitimacy theory to predict more CSR disclosure.

Hoepner and Wilson (2012) contend that legitimacy theory is a good framework for considering banks' reporting of social and environmental impacts. Lawrence, Botes, Collins and Roper (2013) also hint that in their bid to advance the image of being socially responsible, many firms attempt to deceive and manipulate information. However, this attempt can be revoked by the community (Deegan, 2007) by ensuring that, in order to secure their legitimacy, companies must disclose environmental and social impacts information.

\subsection{Global banking industry CSR reporting}

The demand for companies to be transparent and act in a socially responsible manner has been influenced by wider stakeholder activism, globalisation and availability of information. For a company's CSR efforts to have any impact on its business and stakeholders, choosing the appropriate form to communicate is relevant. Long, Doerer and Stewart (2015) assert that currently available multimedia platforms should be exploited, as companies' reportage on social issues had comprehensively increased. According to a KPMG (2011) report, though 250 largest companies are disclosing CSR engagements, 95\% of these companies enthusiastically report their CSR activities. Another study by KPMG (2016) also disclosed that over $80 \%$ of smaller banks are keenly reporting their CSR initiatives.

Firms employing annual reports and corporate websites to communicate have increased as a result of increasing CSR benefits and stakeholder demands (Spence, 2009). A study by Branco and Rodrigues (2006) which sought to compare CSR disclosures dimensions on websites and in annual reports reported that banks in Portugal with higher visibility disclose more 'environment' and 'human resources' information. Banks in India also focus their CSR engagements on customer satisfaction, education, health, environmental marketing and balanced growth (Narwal, 2007). A longitudinal study by Sobhani, Zainuddin, Amran and Baten (2011) on two case banks for ten years in Bangladesh also reported a low proportion (41\%) of community involvement and human resources CSR disclosure. 
A study by Reinig and Tilt (2009), which investigated how CSR disclosures were reported in press releases, found that four Australian banks' CSR initiatives were more directed at community involvement and customer issues. Again, a study conducted by Halabi, Kazi, Dang and Samy (2006) reported that four out of the top ten Australian banks disclose environment, labour practices, and human rights information. Bouvain, Baumann and Lundmark (2013) also conducted a study to compare banks in China and East Asia vis-àvis banks in America. They found that in Japan and South Korea brand value is positively associated with CSR, unlike in America, where banks are interested in green initiatives. These revelations indicate that even countries where CSR regulations predominantly exist, CSR engagements and reporting significantly differ.

Companies should inform customers about their CSR activities using appropriate communication tools, including comprehensive reports and annual reports. A study by Thompson and Zakaria (2004) found that environmental issues were of very low interests to companies in Malaysia as they disclosed most of the products and consumers, employees and human resources, and involvement in community initiatives. In their study on environmental management and CSR disclosures, Kuo, Yeh and Yu (2011) established that Chinese firms and enterprises owned by the State significantly reported on information regarding environmental engagements due to the environmentally sensitive nature of those industries.

According to Birch (2003), the rising call for companies to positively act responsibly has echoed the need to adapt mandatory and non-mandatory disclosure of social responsibility initiatives. Lindblom (1994) noted that CSR reporting enlightens stakeholders about companies' social performance; influences stakeholders' expectations; communicates positive acts; and attempts to manipulate stakeholders' perceptions of certain events regarding the firm. To reach a wider audience at both national and international levels, some companies worldwide increasingly use their corporate website as a means of disclosing CSR initiatives (Moreno \& Capriotti, 2009).

\subsection{CSR reporting in Ghana's banking industry}

According to the European Commission (2016), companies that are accountable for their impact on society practise CSR. Ofori and Hinson (2007) have also hinted that even though varying areas and levels of emphasis exist, the CSR concept remains similar everywhere; however, each company's response to CSR issues is unique and influenced by its size, industry, business culture, stakeholder demands and historical progression. According to Amponsah-Tawiah and Dartey-Baah (2011), multinational enterprises in Ghana mostly focus more on CSR initiatives than small- and medium-sized enterprises do. Most banks are integrating CSR initiatives with their corporate strategies to earn credibility, yet their reporting and disclosures appear to be problematic.

In the banking industry, CSR information is, more often than not, disclosed on a voluntary basis. As a result, to conform to societal expectations, firms disclose CSR information to enhance reputation, improve superior employee satisfaction and retention, and attract a lesser number of directives, etc (Moser \& Martin, 2012). As a means of improving 
stakeholder relationships and business performance, several Ghanaian organisations have employed annual reports and corporate websites as the avenues to issue CSR reports (Hinson et al., 2010).

Hinson et al.'s (2010) study reported that banks disclose CSR initiatives through newspapers, annual reports and television broadcasts among others; listed banks in Ghana report more CSR information than unlisted ones despite the absence of CSR reporting regulations; and bank CSR awardees exhibit poor CSR communication content on their individual company websites than non-awardees do. The study, however, was silent on the dimensions of CSR disclosures posted by local and foreign banks on their company websites. In a sectoral study in Ghana, Amponsah-Tawiah and Dartey-Baah (2011), found that banks focus CSR initiatives on donations to the underprivileged; educational sponsorship to bright but deprived students; restoration of school facilities; and financial support for adult literacy programmes.

\subsection{Conceptual framework}

Branco and Rodrigues' (2006) online CSR reporting framework as depicted in Figure 1, was adapted to track banks' CSR disclosure in Ghana as reported in their annual reports and sourced from their respective corporate websites. The framework classifies CSR reporting into internal and external disclosures. Similarly, recent studies have postulated that the two classifications under which CSR practices fall are internal and external disclosures (Fifka, 2013).

Internal disclosures cover human resources and product and customer initiatives. Human resources capture initiatives regarding the well-being and safety of employees, as well as employee training and compensation (HR Dis.) disclosures whilst product and customer initiatives also capture client displeasure and/or satisfaction, product superiority, and access conditions for customers who are physically challenged (P\&C Dis.). External disclosures, on the other hand, cover initiatives regarding environmental and community engagements. Environmental initiatives capture engagements about the investment and lending policies, the energy conservation of business and the concern for the environment (E Dis.) disclosures while community involvement disclosures also capture engagements that include support and sponsorship for education, sports or recreational projects, and charitable donations and activities (Cl Dis.).

Though the framework includes the internet as a disclosure medium in an analytical category, it does not address any specific conceptual elements pertaining to the online/ internet environment. Again, although the framework presents data about CSR reporting on the internet, this study appears to present data about CSR initiatives reported in annual reports sourced from selected banks' websites. The annual reports were published on the websites, not because banks use the online environment in any particularly innovative way - for example, daily or monthly CSR reporting, or blogs, or any other innovative online media - for CSR reporting.

The absence of such innovative ways of CSR reporting suggests that more people can read the annual reports posted on banks' websites. Disclosures are mostly non-statistical in this 
current study, except where the selected banks have stated the donations amount and/or sponsorship monetary value. Ernst and Ernst (1978:31) postulated that "quantification of a disclosure improves its quality by specifying the amount of effort a company spends in a particular area of social responsibility". Of special interest in adopting this framework is to track CSR disclosures of local and foreign banks, as reported in their annual reports and posted on banks' websites.

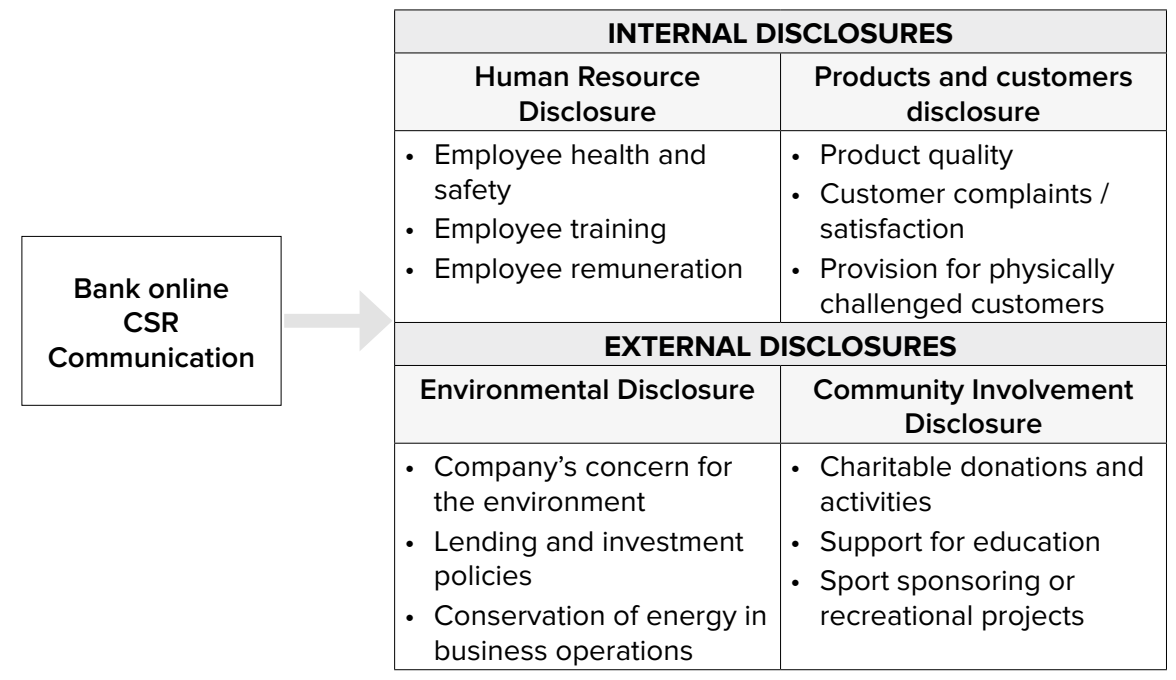

Figure 1: Branco and Rodrigues' (2006) online CSR reporting framework

[Adapted]

\section{Methodology}

A qualitative research design was employed to track and evaluate the level of CSR disclosure of both local and foreign banks operating in Ghana. Initial consideration was given to all 27 banks operating in Ghana within the study period. However, drawing from their company annual reports on CSR disclosure regularity from 2010-2014 financial year ends, as posted on their respective banks' websites, the researchers selected five locally owned and five foreign-owned listed banks, totalling a sample of ten banks. The period of study was chosen because CSR disclosure appeared to have been more consistent.

In order not to rely on other archival records and some foreign and local search engines for CSR information, the researchers' main modus operandi was to browse annual reports sourced from selected banks' websites, and to record only the CSR disclosures reported from 2010-2014 financial year ends. The five local banks selected for the study included CAL Bank (CAL), Ghana Commercial Bank (GCB), HFC Bank (HFC), Fidelity Bank (FB), and Agriculture Development Bank (ADB). The five foreign banks selected included Ecobank (EB), Zenith Bank (ZB), Societé Generale (SG), Standard Chartered Bank (SCB), and Guaranteed Trust Bank (GTB).

The study employed 50 company annual reports posted on the websites of the selected banks. Due to the soaring level of reliability of the information contained therein, earlier studies have emphasised the annual report as an important document concerning 
CSR (Islam, 2013). Identifying CSR disclosures of local and foreign-owned listed banks operating in Ghana over the study period appears to be relevant in terms of contributing to CSR reporting literature in Ghana and beyond.

As a situational study, after collecting all the relevant data sourced from the banks' respective websites, a scoring method was developed to measure the level of CSR disclosures. For this purpose, the researchers employed the binary scoring approach in arriving at the CSR disclosures recorded in the annual reports and posted on the selected banks' websites. This approach is followed in a disclosure study (Jiang et al., 2010). Any CSR item reported in the bank's annual report earns a score of "one", and "zero" otherwise. Finally, the scores of the items were added up to ascertain the concentration of bank CSR disclosure from the annual reports posted on the website, a view shared by Hinson et al. (2010) and Branco and Rodrigues (2006).

Drawing on Branco and Rodrigues' (2006) online CSR reporting framework, this study was grounded in legitimacy and stakeholder theoretical perspectives, to meet stakeholder expectations - customers, employees and the society.

\section{Presentation and discussion of the findings}

\subsection{CSR disclosure of selected banks}

Table 1: CSR disclosure of selected banks

\begin{tabular}{|c|c|c|c|c|c|c|c|c|c|c|c|}
\hline \multirow{2}{*}{$\begin{array}{l}\text { Name } \\
\text { of Bank }\end{array}$} & \multirow{2}{*}{$\begin{array}{c}\text { Disclosure } \\
\text { of CSR }\end{array}$} & \multicolumn{2}{|c|}{ Internal Disclosure } & \multicolumn{2}{|c|}{ External Disclosure } & \multicolumn{5}{|c|}{ Year } & \multirow{2}{*}{$\begin{array}{l}\text { Total } \\
\text { score }\end{array}$} \\
\hline & & HR Dis. & P\&C Dis. & E Dis. & CI Dis. & $\mathrm{Y} 1$ & Y2 & Y3 & Y4 & Y5 & \\
\hline \multicolumn{12}{|l|}{$\begin{array}{l}\text { LOCAL } \\
\text { BANKS }\end{array}$} \\
\hline \multicolumn{12}{|c|}{ CAL Bank } \\
\hline 2010 & 1 & 0 & 0 & 0 & 1 & 2 & & & & & \\
\hline 2011 & 1 & 1 & 0 & 1 & 0 & & 3 & & & & \\
\hline 2012 & 1 & 1 & 0 & 0 & 1 & & & 3 & & & \\
\hline 2013 & 1 & 1 & 0 & 0 & 1 & & & & 3 & & \\
\hline \multirow[t]{2}{*}{2014} & 1 & 0 & 0 & 1 & 1 & & & & & 3 & \\
\hline & 5 & 3 & 0 & 2 & 4 & & & & & & 14 \\
\hline \multicolumn{12}{|l|}{ GCB } \\
\hline 2010 & 1 & 0 & 0 & 0 & 1 & 2 & & & & & \\
\hline 2011 & 0 & 0 & 0 & 0 & 0 & & 0 & & & & \\
\hline 2012 & 1 & 0 & 0 & 0 & 1 & & & 2 & & & \\
\hline 2013 & 1 & 0 & 0 & 0 & 1 & & & & 2 & & \\
\hline \multirow[t]{2}{*}{2014} & 1 & 0 & 0 & 0 & 1 & & & & & 2 & \\
\hline & 4 & 0 & 0 & 0 & 4 & & & & & & 8 \\
\hline
\end{tabular}




\begin{tabular}{|c|c|c|c|c|c|c|c|c|c|c|c|}
\hline \multirow{2}{*}{$\begin{array}{l}\text { Name } \\
\text { of Bank }\end{array}$} & \multirow{2}{*}{$\begin{array}{l}\text { Disclosure } \\
\text { of CSR }\end{array}$} & \multicolumn{2}{|c|}{ Internal Disclosure } & \multicolumn{2}{|c|}{ External Disclosure } & \multicolumn{5}{|c|}{ Year } & \multirow{2}{*}{$\begin{array}{l}\text { Total } \\
\text { score }\end{array}$} \\
\hline & & HR Dis. & P\&C Dis. & E Dis. & Cl Dis. & Y1 & Y2 & Y3 & Y4 & Y5 & \\
\hline \multicolumn{12}{|l|}{$A D B$} \\
\hline 2010 & 1 & 0 & 0 & 0 & 1 & 2 & & & & & \\
\hline 2011 & 1 & 0 & 0 & 0 & 1 & & 2 & & & & \\
\hline 2012 & 1 & 0 & 0 & 0 & 1 & & & 2 & & & \\
\hline 2013 & 1 & 0 & 0 & 0 & 1 & & & & 2 & & \\
\hline \multirow[t]{2}{*}{2014} & 1 & 0 & 0 & 1 & 1 & & & & & 3 & \\
\hline & 5 & 0 & 0 & 1 & 5 & & & & & & 11 \\
\hline \multicolumn{12}{|l|}{ HFC } \\
\hline 2010 & 1 & 0 & 0 & 0 & 1 & 2 & & & & & \\
\hline 2011 & 1 & 0 & 0 & 1 & 1 & & 3 & & & & \\
\hline 2012 & 1 & 0 & 0 & 1 & 1 & & & 3 & & & \\
\hline 2013 & 1 & 0 & 0 & 1 & 1 & & & & 3 & & \\
\hline \multirow[t]{2}{*}{2014} & 1 & 0 & 0 & 1 & 1 & & & & & 3 & \\
\hline & 5 & 0 & 0 & 4 & 5 & & & & & & 14 \\
\hline \multicolumn{12}{|l|}{$\begin{array}{l}\text { Fidelity } \\
\text { Bank }\end{array}$} \\
\hline 2010 & 1 & 0 & 0 & 0 & 1 & 2 & & & & & \\
\hline 2011 & 1 & 0 & 0 & 0 & 1 & & 2 & & & & \\
\hline 2012 & 1 & 0 & 0 & 0 & 1 & & & 2 & & & \\
\hline 2013 & 1 & 0 & 0 & 0 & 1 & & & & 2 & & \\
\hline \multirow[t]{2}{*}{2014} & 1 & 0 & 0 & 0 & 1 & & & & & 2 & \\
\hline & 5 & 0 & 0 & 0 & 5 & & & & & & 10 \\
\hline \multicolumn{12}{|c|}{$\begin{array}{l}\text { FOREIGN } \\
\text { BANKS }\end{array}$} \\
\hline \multicolumn{12}{|l|}{ Ecobank } \\
\hline 2010 & 1 & 0 & 0 & 0 & & 2 & & & & & \\
\hline 2011 & 1 & 0 & 0 & 0 & 1 & & 2 & & & & \\
\hline 2012 & 1 & 0 & 0 & 0 & 1 & & & 2 & & & \\
\hline 2013 & 1 & 0 & 0 & 1 & 1 & & & & 3 & & \\
\hline \multirow[t]{2}{*}{2014} & 1 & 0 & 0 & 1 & 1 & & & & & 3 & \\
\hline & 5 & 0 & 0 & 2 & 5 & & & & & & 12 \\
\hline \multicolumn{12}{|l|}{ GT Bank } \\
\hline 2010 & 1 & 0 & 0 & 0 & 1 & 2 & & & & & \\
\hline 2011 & 1 & 0 & 0 & 0 & 1 & & 2 & & & & \\
\hline 2012 & 1 & 1 & 0 & 0 & 1 & & & 3 & & & \\
\hline 2013 & 1 & 1 & 0 & 0 & 1 & & & & 3 & & \\
\hline \multirow[t]{2}{*}{2014} & 1 & 1 & 0 & 0 & 1 & & & & & 3 & \\
\hline & 5 & 3 & 0 & 0 & 5 & & & & & & 13 \\
\hline
\end{tabular}




\begin{tabular}{|c|c|c|c|c|c|c|c|c|c|c|c|}
\hline \multirow{2}{*}{$\begin{array}{l}\text { Name } \\
\text { of Bank }\end{array}$} & \multirow{2}{*}{$\begin{array}{c}\text { Disclosure } \\
\text { of CSR }\end{array}$} & \multicolumn{2}{|c|}{ Internal Disclosure } & \multicolumn{2}{|c|}{ External Disclosure } & \multicolumn{5}{|c|}{ Year } & \multirow{2}{*}{$\begin{array}{l}\text { Total } \\
\text { score }\end{array}$} \\
\hline & & HR Dis. & P\&C Dis. & E Dis. & Cl Dis. & Y1 & Y2 & Y3 & Y4 & Y5 & \\
\hline \multicolumn{12}{|l|}{$\begin{array}{l}\text { SSB } \\
\text { now SG }\end{array}$} \\
\hline 2010 & 0 & 0 & 0 & 0 & 0 & 0 & & & & & \\
\hline 2011 & 0 & 0 & 0 & 0 & 0 & & 0 & & & & \\
\hline 2012 & 1 & 1 & 0 & 1 & 1 & & & 4 & & & \\
\hline 2013 & 1 & 1 & 0 & 1 & 1 & & & & 4 & & \\
\hline \multirow[t]{2}{*}{2014} & 1 & 1 & 0 & 1 & 1 & & & & & 4 & \\
\hline & 3 & 3 & 0 & 3 & 3 & & & & & & 12 \\
\hline \multicolumn{12}{|l|}{$\begin{array}{l}\text { Zenith } \\
\text { Bank }\end{array}$} \\
\hline 2010 & 1 & 1 & 1 & 0 & 1 & 4 & & & & & \\
\hline 2011 & 1 & 0 & 0 & 0 & 1 & & 2 & & & & \\
\hline 2012 & 1 & 1 & 1 & 0 & 1 & & & 4 & & & \\
\hline 2013 & 1 & 0 & 0 & 0 & 1 & & & & 2 & & \\
\hline \multirow[t]{2}{*}{2014} & 1 & 0 & 0 & 0 & 1 & & & & & 2 & \\
\hline & 5 & 2 & 2 & 0 & 5 & & & & & & 14 \\
\hline \multicolumn{12}{|l|}{ SCB } \\
\hline 2010 & 1 & 0 & 0 & 0 & 0 & 1 & & & & & \\
\hline 2011 & 1 & 1 & 0 & 0 & 0 & & 2 & & & & \\
\hline 2012 & 1 & 0 & 0 & 0 & 1 & & & 2 & & & \\
\hline 2013 & 1 & 0 & 0 & 0 & 0 & & & & 1 & & \\
\hline \multirow[t]{2}{*}{2014} & 1 & 0 & 0 & 0 & 0 & & & & & 1 & \\
\hline & 5 & 1 & 0 & 0 & 1 & & & & & & 7 \\
\hline
\end{tabular}

Table 1 shows the selected local and foreign banks' CSR disclosure from 2010 to 2014. With regard to CSR disclosures, though non-mandatory, the findings indicated that the banks posted a far-reaching amount of information about CSR initiatives on their respective websites, which leads the researchers to conclude that CSR reporting in Ghana's banking industry is prevalent. All the selected banks attained five points each over the five-year study period. However, GCB, which is a local bank, did not report any CSR disclosure in 2011 and thus attained four points. Similarly, SG, which is a foreign bank, also attained three points as there were no CSR disclosures in 2010 and 2011. The results showed significant differences of CSR disclosure between local and foreign banks in Ghana. Internal disclosures covered CSR initiatives categorised under human resource (12 points) and product and customer (two points), while external disclosures also covered CSR initiatives categorised under community involvement (41 points) and environmental (12 points). CSR initiatives reported were mainly external disclosures.

The observations presented from these findings suggest that although CSR disclosures were inconsistent over the study period, all selected banks appreciated the significance of communicating some CSR initiatives in their annual reports as posted on their websites. 
CSR reporting plays an imperative role and requires banks to communicate CSR efforts through different communication platforms, yet none of the selected local and foreign banks recorded on all four CSR disclosure dimensions. As hinted by Hinson et al. (2010), an integration of online presence with firms' activities is fairly new in Ghana owing to the non-existence of CSR reporting regulations; however, the results indicated a growing interest in CSR disclosure in the banking industry.

\subsection{Local banks' CSR disclosures}

With respect to CSR disclosures of the local banks, the findings revealed the following results: CAL (25\%), HFC (25\%), ADB (19\%), FB (17\%) and GCB (14\%). Local banks reported both internal and external disclosures but areas of CSR efforts mottled.

Internal disclosures covered both human resource as well as product and customer issues. The study found out that just one local bank (CAL bank) reported on internal disclosures (specifically human resource - employee and management training, and health and safety issues) from 2011 to 2013, thereby obtaining three points. Concerning CSR internal disclosures under human resource initiatives, CAL Bank was more oriented towards capacity building, employee empowerment and training programmes. CAL Bank can use this disclosure as a strategy to attract skilled employees, improve corporate image and enhance competitiveness. The remaining four local banks did not report any CSR initiatives on human resource disclosure.

Unexpectedly, CSR initiatives categorised under product and customer disclosures, which were meant to address issues of customer complaints and/or satisfaction, the provision for physically challenged customers and product quality received no reportage of CSR efforts and disclosure over the study period. Concerning CSR engagements and internal disclosure, the findings appear to suggest that local banks in Ghana do not often consider customer complaints, product quality issues and provision for physically challenged customers as very fundamental to the banks' success. Even though compliance is still not compulsory in Ghana, some businesses have adopted the concept as a business strategy towards gaining competitive advantage (Kuada \& Hinson, 2012). The findings suggest that local banks prefer to empower employees than address customer satisfaction issues.

Local banks recorded external disclosures, which encapsulate community involvement and environmental issues. Community involvement which covered support and sponsorship for education, sports or recreational projects, and charitable donations and activities (CI Dis.), scored 23 points collectively. ADB, HFC and FB scored five points each. GCB and CAL banks also scored four points each. Three out of the five local banks that reported on environmental disclosure which captured initiatives such as the investment and lending policies, the energy conservation of business and the concern for the environment (including cleanliness activities and projects) scored seven points collectively and yielded the following results: HFC (four points), CAL bank (two points) and ADB (one point). Concerning environmental disclosure, HFC stands tall amongst the local banks. Local banks' CSR engagements tend to focus more on community involvement initiatives than environmental initiatives. 
This finding supports Reinig and Tilt's (2009) study of CSR disclosure which found that by employing press releases, four Australian banks' CSR disclosures were mainly focused on initiatives concerned with customers and community involvement engagements. The finding again contradicts Sobhani et al.'s (2011) longitudinal study in Bangladesh on two case banks for ten years that reported a low proportion (41\%) of community involvement and human resources CSR disclosure.

\subsection{Foreign banks' CSR disclosures}

The findings indicated that collectively, foreign banks yielded the following results: ZB (25\%), EB (22\%), SG (22\%), GT (22\%) and SCB (9\%), and reported both internal and external disclosures. However, areas of CSR efforts speckled. Internal disclosures which captured human resource and product and customer reported that one foreign bank (EB bank) made no disclosure on human resource - employee and management training, and health and safety issues, from 2011 to 2014. However, the remaining foreign banks scored GT (three points), SG (three points), ZB (two points), and SCB (one point). Indicatively, the four foreign banks' (GT, SG, ZB and SCB) CSR internal disclosures under human resource were more oriented towards employee capacity building and training programmes, and could equally use these disclosures as a strategy to attract skilled employees and enhance competitiveness.

Only one foreign bank (ZB) recorded CSR internal disclosures under product and customer disclosures (specifically on product quality innovation). This finding suggests that as part of its CSR, ZB has integrated product quality innovation into its operations. Again, only one foreign bank (SCB) recorded the amount spent on CSR initiatives. This amount declaration supported Ernst and Ernst's (1978:31) assertion that to improve disclosure quality, a company must specify the amount of effort it expended on the initiative. Unlike the local banks, foreign banks focused more on human resource than product and customer disclosures and scored eight points (five points higher than local banks' disclosure). The findings also suggest that foreign banks prefer to empower employees than to address customer satisfaction issues.

Foreign banks also recorded some external disclosures, which captured issues concerning environmental and community contribution. The environmental disclosure, which considered the investment and lending policies, the energy conservation of business and the concern for the environment, scored five points (two points short of local banks' disclosure). The only two foreign banks that made environmental disclosures scored SG (three points) and Ecobank (two points). The remaining three foreign banks (SCB, GT and ZB) did not report on any environmental disclosures. Internal CSR disclosure which covered initiatives regarding the well-being and safety of employees, as well as employee training and compensation (HR Dis.) scored eight points (five points more than local banks' performance) with GT and SG scoring three points each. Regarding product and customer initiatives that also capture client displeasure and/or satisfaction, product superiority, and access conditions for customers who are physically challenged (P\&C Dis.), EB and SCB had no disclosures; however, ZB recorded two points. 
As hinted by Preston and Post (2012), to legitimise corporate CSR actions, the corporate exposé is prepared in response to environmental factors. Indicatively, from 2010-2014 financial year ends, the findings reported poor environmental disclosures, and thus contradict Preston and Post's (2012) submission. Community involvement disclosure, which captured support and sponsorship for education, sports or recreational projects, and charitable donations and activities (CI Dis.), scored EB (five points), GT (five points), ZB (five points), SG (three points) and SCB (one point). Community involvement reported the highest CSR efforts disclosed by foreign banks despite scoring 19 points (which is four points less than local banks' disclosure). EB and SG are the only two foreign banks that undertook environmental initiatives (external disclosure) and reported in the 2013 and 2014, and 2012-2014 periods respectively.

Drawing from legitimacy and stakeholder theories, this current study found that despite the absence of CSR reporting regulations, local and foreign banks in Ghana voluntarily report CSR disclosures. Indicatively, this initiative appears to signal that CSR disclosure intensity can be increased where there is advanced need to display conformity with public obligations. Though disclosure is voluntary, most selected local and foreign banks appear to have reported on CSR disclosures.

The stakeholder theory sought to suggest that firms should not only consider profit maximisation but that they should also consider other goals (Maignan \& Farrell, 2004), and must devote some resource commitments towards CSR engagements irrespective of the business's nature, size and type. As hinted by Glennie and Lodhia (2013), to foresee additional CSR disclosure in economies and industries with growing environmental agendas, the legitimacy theory can be employed. However, without a stronger environmental agenda in Ghana, the banking industry appears to be reporting on CSR environmental disclosure. These findings support Alawi and Rahma's (2011) assertion that to convince and gain community support, specific information about companies' legitimate activities must be voluntarily disclosed to the society via communication (Ihlen et al., 2014).

\section{Conclusion and recommendations}

the main aim of this study was to track the development of local and foreign banks' CSR disclosure in Ghana. The annual reports posted on the selected banks' websites, over a five-year period, served as the data source. Using Branco and Rodrigues' (2006) CSR online reporting framework and employing the legitimacy and stakeholder theoretical underpinnings, this current article employed a situational approach by means of a nonstatistical CSR reporting of selected local and foreign banks in Ghana. The study found that in Ghana's banking industry, both local and foreign banks reported some internal and external disclosures, but paid more attention to external disclosures, which covered CSR engagements in education, sports development and health, but with uneven focus. Two foreign and three local banks reported on the aforementioned environmental disclosures. 
Concerning internal disclosures, none of the local banks, except one foreign bank, reported on product and customer initiatives. These findings suggest that local banks are less interested in addressing customer complaints and/or enhancing satisfaction, improving product quality, and providing for the physically challenged customers. One local bank and four foreign banks also reported on human resource initiatives which covered employee and management training, and health and safety issues. These findings also suggest that foreign banks appear to be more interested in employee empowerment, remuneration and training programmes than their local counterparts. Overall, foreign banks reported more CSR internal disclosures than the local banks.

Concerning external disclosures, the study revealed that three local banks and two foreign banks reported on environmental initiatives which captured lending and investment policies, concern for the environment, and energy conservation in business. Again, local banks are more interested in education about environmental cleanliness, tree planting and sanitation programmes as compared to their foreign counterparts. Unexpectedly, all the local and foreign banks reported on CSR engagements and posted on their websites community involvement disclosures which cover support and sponsorship for education, sports or recreational projects, and charitable donations and activities. Even though foreign banks disclosed higher CSR initiatives in community involvement, the accumulated scores indicated that foreign banks scored 19 points (which is four points less than the local banks' disclosure of 23 points). Local banks, therefore, reported more CSR external disclosures than foreign banks.

Indeed, the researchers expected that foreign banks with European and American backgrounds would report adequately on CSR disclosures, since CSR reporting appeared to be mandatory in their respective parent countries. However, reportage appeared to be inadequate and inconsistent. This poor CSR engagement and disclosure can be attributed to the absence of CSR reporting regulations in Ghana.

Drawing from Branco and Rodrigues' (2006) online CSR reporting framework, the researchers recommend the establishment of CSR departments in all the banks conducting business in Ghana. The department should oversee all CSR initiatives and reporting; improve annual reports' CSR disclosures; and create particularly daily or monthly CSR reporting, blogs, or any other innovative online media to enhance online environment initiatives. This means that CSR reporting must be reported uniquely and distinct from other reports posted in annual reports on banks' websites.

It is again recommended that the departments should collaborate with stakeholders to spread CSR initiatives amongst all four dimensions over time, as well as initiate and formulate proper guidelines for CSR initiatives and implementation. This initiative can be achieved when a proper CSR reporting regulation is developed. The uneven focus of CSR initiatives and reporting by the banks will be reduced or eliminated, and particularly so when it is linked to Ghana's developmental policy directions.

Again, it is recommended that the framework's classification of CSR reporting into internal and external disclosures serves as an avenue for the banking industry to mandate 
either the local or foreign banks to focus CSR engagements on either internal of external initiatives and/or vice versa as a development agenda. The industry can, therefore, mandate local banks to only consider external CSR engagements whilst the foreign counterparts can consider internal CSR initiatives. Alternatively, the banking industry can also focus CSR engagements and disclosure under any of the classifications. Other industries can also be mandated to consider CSR engagement and disclosure on the other classifications. It is also recommended that banks integrate internal and external disclosures and clearly communicate this information to its stakeholders to enhance effective online CSR communication and competitive posture.

Increased stakeholder engagements to discuss areas of critical CSR initiatives are also highly recommended. The findings expose vital information that is useful for researchers, governments, law makers, banks, policy makers and other corporate bodies alike. For researchers and practitioners, the findings appear to push towards appreciating CSR disclosure trends in Ghana. Furthermore, the government of Ghana must ensure that CSR disclosure is mandatory and fully legislated. Strict compliance will raise CSR reporting standards and practices in Ghana. Strategic efforts to use the online environment in innovative ways for CSR reporting should also be encouraged. Reliance on CSR reporting in annual reports posted on company websites is highly inadequate, and thus weakens the rationale for CSR disclosures.

Limiting the study to the banking industry in Ghana and adopting a qualitative approach have provided some foundation for further quantitative studies. Future studies could look at comparative studies and more longitudinal studies of CSR disclosure amongst other industries or countries to ascertain the CSR disclosure position in Ghana. More case studies and empirical studies must be conducted to validate these results and to provide in-depth information about specific banks' CSR disclosures. Employees' perceptions and conceptualisations of CSR and the factors that influence CSR engagement and reportage can be studied. Another study could consider analysing the contents of some newspaper CSR reportage initiatives in certain selected industries in Ghana.

\section{References}

Alawi, N.A.M. \& Rahman, A.A. (2011). Corporate social responsibility disclosure in response to CSR award with the moderating effect of family group affiliation in Yemen. In: Proceedings of the 2011 international research conference and colloquium. College of Business, University Utara Malaysia. http://www.unirazak. edu.my/colloquium2011/proceedings [Accessed 12 September 2016].

Amponsah-Tawiah, K. \& Dartey-Baah, K. (2011). Corporate social responsibility in Ghana. International Journal of Business and Social Science, 2:107-112.

Arvidsson, S. (2010). Communication of corporate social responsibility: A study of the views of management teams in large companies. Journal of Business Ethics, 96:339-354. https://doi.org/10.1007/s10551-010-0469-2

Bawumia, M., Owusu-Danso, T. \& McIntyre, A. (2008). Ghana's reforms transform its financial sector. IMF Survey Magazine: Countries \& Region, 1-4.

Boon, E.K. \& Ababio, F. (2009). Corporate social responsibility in Ghana: Lessons from the mining sector. In: IAIIA09 Conference proceedings, impact assessment and human well-being. 
Birch, D. (2003). Corporate social responsibility: Some key theoretical issues and concepts for new ways of doing business. Journal of New Business Ideas and Trends, 1:1-19.

Bouvain, P., Baumann, C. \& Lundmark, E. (2013). CSR in financial services: A comparison between Chinese and East Asia's banks vis-à-vis American banks. International Journal of Bank Marketing, 31:420-439. https://doi.org/10.1108/IJBM-05-2012-0054

Branco, M. \& Rodrigues, L. (2006). Communication of corporate social responsibility by Portuguese banks: a legitimacy theory perspective. Corporate Communications, An International Journal, 11:232-248. https:// doi.org/10.1108/13563280610680821

Deegan, C. (2007). Organizational legitimacy as a motive for sustainability reporting. In: J. Unerman, J. Bebbington \& B. O’Dwyer (eds.). Sustainability Accounting and Accountability. Abingdon: Routledge. 127-149. https://doi.org/10.4324/NOE0415384889.ch7

Du, S., Bhattacharya, C.B. \& Sen, S. (2010). Maximizing business returns to corporate social responsibility (CSR): the role of CSR communication. International Journal of Management Reviews, 12:8-19. https://doi. org/10.1111/j.1468-2370.2009.00276.x

Ernst and Ernst (1978). Social responsibility disclosure: 1978 Survey. Survey of fortune 500 annual reports. Cleveland, O.H.: Ernst and Ernst.

European Commission. (2016). Corporate social responsibility (CSR). http://ec.europa.eu/growth/industry/ corporate-socialresponsibility/indxen.htm [Accessed 2 July 2017].

Fifka, M.S. 2013. Corporate responsibility reporting and its determinants in comparative perspective - a review of the empirical literature and a meta-analysis. Business Strategy and the Environment, 22:1-35. https://doi.org/10.1002/bse.729

Ghana Banking Survey. (2014). The future of banking. What's next? PricewaterhouseCoopers.

Glennie, M. \& Lodhia, S. (2013). The influence of internal organisational factors on corporate-community partnership agendas: an Australian case study. Meditari Accountancy Research, 21:52-67. https://doi. org/10.1108/MEDAR-07-2012-0022

Gray, R. (2010). Is accounting for sustainability actually accounting for sustainability ... and how would we know? An exploration of narratives of organisations and the planet. Account Org Soc, 35:47-62. https:// doi.org/10.1016/j.aos.2009.04.006

Gray, R., Kouhy, R. \& Lavers, S. (1995). Corporate social and environmental reporting: A review of the literature and a longitudinal study of UK Disclosure. Accounting, Auditing, and Accountability, 8:47-77. https://doi.org/10.1108/09513579510146996

Guthrie, J., Cuganesan, S. \& Ward, L. (2008). Industry specific and environmental reporting: The Australian food and beverage industry. Accounting Forum, 32:1-15. https://doi.org/10.1016/j.accfor.2007.10.001

Halabi, A., Kazi, A., Dang, V. \& Samy, M. (2006). Corporate social responsibility. Monash Business Review, 12:22-35.

Hamid, F.Z.A. (2004). Corporate social disclosure by banks and finance companies: Malaysian evidence. Corporate Ownership and Control, 1:118-130. https://doi.org/10.22495/cocv1i4p10

Hinson, R. (2011). Online CSR reportage of award-winning versus non-award-winning banks in Ghana. Journal of Information, Communication, and Ethics in Society, 9:102-115. https://doi.org/10.1108/14779961111148622

Hinson, R., Boateng, R.\& Madichie, N.(2010). Corporate social responsibility activity reportage on bank websites in Ghana. International Journal of Bank Marketing, 28:498-518. https://doi.org/10.1108/02652321011085176

Hinson, R.E., Van Zyl, H. \& Agbleze, S. (2014). An interrogation of the dialogic potential of insurance firm websites in Ghana. Information Development, 30:59-69. https://doi.org/10.1177/0266666913477879

Hoepner, A. \& Wilson, J. (2012). Social, environmental, ethical and trust (SEET) issues in banking: An overview. http://papers.ssrn.com/sol3/papers.cfm?abstract_id=1686240 [Accessed 22 November 2016].

Holme, R. \& Watts, P. (2000). Corporate social responsibility: Making good business sense. Geneva: World business council for sustainable development. 
Huang, H. \& Zhao, Z. (2016). The influence of political connection on corporate social responsibility evidence from listed private companies in China. International Journal of Corporate Social Responsibility, 1(9). https://doi.org/10.1186/s40991-016-0007-3

Ihlen, Ø., May, S. \& Barlett, J.L. (2014). Four aces: Bringing communication perspectives to corporate social responsibility. In: R. Tench, W. Sun \& B. Jones (eds.). Communicating Corporate Social Responsibility: Perspectives and Practice.

Isenmann, H. (2006). The handbook of communication and corporate social responsibility. John Wiley \& Sons.

Islam, M.T. (2013). Linking corporate social responsibility expenditure to the performance of banks: A study in the banking sector of Bangladesh. Bank Parikrama, 38:109-130.

Jiang, C.L., Bazarova, N.N. \& Hancock, J.T. (2011). The disclosure-intimacy link in computer-mediated communication: An attributional extension of the hyperpersonal model. Human Communication Research, 37:58-77. https://doi.org/10.1111/j.1468-2958.2010.01393.x

Kitora, Y. \& Okuda, S.Y. (2017). The effects and determinants of extensive disclosure: Evidence from Japan. Corporate Ownership and Control, 5:212-224.

Kotler, P. (2003). Marketing management. New Jersey: Prentice Hall.

KPMG. (2011). KPMG international survey of corporate responsibility reporting 2011 KPMG International Cooperative.

KPMG. (2016). Corporate responsibility reporting in the banking sector. Key findings from the KPMG survey of corporate responsibility reporting 2015. July 2016. https://assets.kpmg.com/content/dam/kpmg/xx/ pdf/2016/08/corporate-responsibility-banking-sector.pdf [Accessed 29 June 2017].

Kuada, J. \& Hinson, R. (2012). Corporate social responsibility (CSR) practices of foreign and local companies in Ghana. Thunderbird International Business Review, 54:521-536. https://doi.org/10.1002/tie.21481

Kuo, L., Yeh, C. \& Yu, H. (2011). Disclosure of corporate social responsibility and environmental management: Evidence from China. Corporate Social Responsibility and Environmental Management. http://onlinelibrary. wiley.Com/doi/10.1002/csr.274/abstract [Accessed 8 June 2017].

Lawrence, S.R., Botes, V., Collins, E. \& Roper, J. (2013). Does accounting construct the identity of firms as purely self-interested or as socially responsible? Meditari Accountancy Research, 21:144-160. https://doi. org/10.1108/MEDAR-09-2012-0030

Lindblom, C.K. (1994). The implication of organizational legitimacy for corporate social performance and disclosure. Critical Perspectives on Accounting Conference. New York, N.Y.

Long, S.D., Doerer, S. \& Stewart, O. (2015). Virtual ethnography: Corporate virtual diversity communication. Qualitative Research in Organizations and Management: An International Journal, 10:175-200. https://doi. org/10.1108/QROM-03-2014-1207

Maignan, I. \& Ferrell, O.C. (2004). Corporate social responsibility and marketing: An integrative framework, Journal of the Academy of Marketing Science, 1:3-19. https://doi.org/10.1177/0092070303258971

Moreno, A. \& Capriotti, P. (2009). Communicating CSR citizenship and sustainability on the web. Journal of Communication Management, 13:157-175. https://doi.org/10.1108/13632540910951768

Morsing, M. \& Schultz, M. (2006). Corporate social responsibility communication: Stakeholder information, response and involvement strategies. Business Ethics: A European Review, 5:323-338. https://doi. org/10.1111/j.1467-8608.2006.00460.x

Narteh, B. (2013). SME bank selection and patronage behaviour in the Ghanaian banking industry. Management Research Review, 36:1061-1080. https://doi.org/10.1108/MRR-06-2012-0147

Narwal, M. (2007). CSR initiatives of the Indian banking industry. Social Responsibility Journal, 3:49-60. https://doi.org/10.1108/17471110710840233

Newson, M. \& Deegan, C. (2002). Global expectations and their association with corporate social disclosure practices in Australia, Singapore and South Korea. The International Journal of Accounting, 37:183-213. https://doi.org/10.1016/S0020-7063(02)00151-6 
Nielsen, A.E. \& Thomsen, C. (2012). Corporate social responsibility (CSR) management and marketing communication: research streams and themes. Hermes - Journal of Language and Communication in Business, 49. http://download2.hermes.asb.dk/archive/download/Hermes-49-5nielsen\&thomsen.pdf [Accessed 12 September 2016].

Ofori, D. \& Hinson, R. (2007). Corporate social responsibility (CSR) perspectives of leading firms in Ghana. Corporate Governance, 7:178-193. https://doi.org/10.1108/14720700710739813

Owen, D. (2008). Chronicles of wasted time? A personal reflection on the current state of, and future prospects for social and environmental accounting research. Accounting, Auditing \& Accountability Journal, 21:240-267. https://doi.org/10.1108/09513570810854428

Porter, M.E. \& Kramer, M.R. (2006). The link between competitive advantage and corporate social responsibility. Harvard Business Review, 84:78-92.

Reinig, C.J. \& Tilt, C.A. (2009). Corporate social responsibility issues in media releases: a stakeholder analysis of Australian banks. Issues in Social and Environmental Accounting, 2:176-197. https://doi.org/10.22164/ isea.v2i2.31

Schmeltz, L. (2012). Consumer-oriented CSR communication: Focusing on ability or morality? Corporate Communication: An International Journal, 18:193-211.

Sloan, P. 2009. Redefining stakeholder engagement. Journal of Corporate Citizenship, 36:25-40. https://doi. org/10.9774/GLEAF.4700.2009.wi.00005

Sobhani, F.A. Zainuddin, Y. Amran, A. \& Baten, M.A. (2011). Corporate sustainability disclosure practices of selected banks: a trend analysis. African Journal of Business Management, 5:2794-2804.

Spence, C. (2009). Social and environmental reporting and the corporate ego. Business Strategy and the Environment, 18:254-265. https://doi.org/10.1002/bse.600

Thompson, P. \& Zakaria Z. (2004). Corporate social responsibility reporting in Malaysia progress and prospects. Journal of Corporate Citizenship, 13:125-136. https://doi.org/10.9774/GLEAF.4700.2004. sp.000014

Tuokuu, X.F.D. \& Amponsah-Tawiah, K. (2016). Corporate social responsibility: Is it an alternative to government? Journal of Global Responsibility, 7:26-38. https://doi.org/10.1108/JGR-05-2015-0007

Ullmann, A. (1985). Data in search of a theory: A critical examination of the relationship among social performance, social disclosure, and economic performance. Academy of Management Review, 10:540-577. https://doi.org/10.21236/ADA158975

Visser, W. (2008). Corporate social responsibility in developing countries. In A. Crane, A. McWilliams, D. Matten, J. Moon \& D. Siegel (eds.). The Oxford Handbook of Corporate Social Responsibility. Oxford: Oxford University Press. 473-479.

Wanderley, L.S.O., Lucian, R., Farache, F. \& De Sousa Filho, J.M. (2008). CSR information disclosure on the web: a context-based approach analysing the influence of country of origin and industry sector. Journal of Business Ethics, 82:369-378. https://doi.org/10.1007/s10551-008-9892-z 